\title{
The Agreement and devolved social security: a missed opportunity for socio-economic rights in Northern Ireland?
}

\author{
MARK SIMPSON
}

Ulster University*

\begin{abstract}
$\underline{\text { Abstract }}$
The UK government made three key human rights-related commitments in the Good Friday Agreement, the basis for the restoration of devolution and transition from conflict to peace in Northern Ireland: to incorporate the European Convention on Human Rights into Northern Ireland law; to consider proposals for a regional Bill of Rights; and to ensure compliance with the state's international obligations in the region. While ECHR compliance is required of devolved institutions by the constitutional legislation, the prospects of a Bill of Rights being enacted appears limited and oversight of compliance with other international obligations is unsatisfactorily placed in political, rather than judicial, hands. Consequently, protection of socio-economic rights beyond those covered by the ECHR is weak. This paper argues that judicial protection of socio-economic rights - whether in the form of a Bill of Rights or the incorporation of additional buman rights agreements into Northern Ireland law - is required for full implementation of the Agreement. It then considers the implications of such a step for social security in the region. The concluding section highlights political and fiscal implications that would have to be considered.
\end{abstract}

\section{Introduction and context}

The Good Friday Agreement ${ }^{1}$ was signed by most major political groupings in Northern Ireland and two national governments, then endorsed by the electorate in simultaneous referenda in Northern Ireland and the Republic of Ireland in $1998 .^{2}$ The Agreement was struck in pursuit of two main objectives. First, to restore devolved government to Northern Ireland - the world's first 'perfect example of devolution'3 but without stable regional

* Research completed under the supervision of Gráinne McKeever (School of Law) and Ann Marie Gray (School of Criminology, Politics and Social Policy), Ulster University. The author would like to thank the journal's anonymous reviewers for their useful comments.

1 Northern Ireland Office, Agreement Reached in the Multi-party Negotiations (Cmnd 3883, NIO 1998).

2 Strictly speaking, the referendum in the Republic of Ireland, although generally portrayed as an endorsement of the Agreement, approved only the amendment of that state's constitution as proposed by the Agreement: see N Whyte, 'The 1998 Referendums' (ARK 14 January 2001/17 February 2002) <www.ark.ac.uk/ elections/fref98.htm> accessed 26 August 2014.

3 'An American professor' cited by J I Cook, 'Financial Relations between the Exchequers of the United Kingdom and Northern Ireland' in F H Newark, J I Cook, D A E Harkness, L G P Preer and D G Neill, Devolution of Government: The Experiment in Northern Ireland (George Allen \& Unwin 1953) 18. 
representative institutions since $1972 .{ }^{4}$ Second, to finally resolve the 'Irish question' in UK politics by putting in place a wider peace settlement. ${ }^{5}$

The concepts of human rights and equality are central to the Agreement, reflecting the widely recognised role of inequality, human rights abuses and discrimination as features and drivers of conflict in Northern Ireland. ${ }^{6}$ However, their prominence is also consistent with a wider concern with human rights and equality of opportunity that found repeated legislative expression throughout 13 years of New Labour government in the UK. ${ }^{7}$ Three Agreement provisions are of most interest to this paper. The first, incorporation of the European Convention on Human Rights (ECHR) into Northern Ireland law, has been delivered. ${ }^{8}$ The second, the appointment of a commission to identify supplementary rights that require judicial protection on the basis of 'the particular circumstances of Northern Ireland'9 has resulted in the publication of recommendations, ${ }^{10}$ but not their implementation. Finally, the stipulation that Parliament should legislate as necessary to ensure the United Kingdom's international obligations are met in respect of Northern Ireland' has received comparatively little attention to date, but will be crucial to the present discussion. ${ }^{11}$

The context for this article is a long-standing impasse in the region's five-party Northern Ireland Executive (the Executive) regarding a proposed Welfare Reform Bill. ${ }^{12}$ The Bill as originally presented to the Northern Ireland Assembly would have continued the longestablished practice of operating parallel but in most respects identical systems of social security for Great Britain and for Northern Ireland ${ }^{13}$ by replicating reforms approved by the UK Parliament for Great Britain. ${ }^{14}$ The Bill was introduced to the Assembly in October 2012, completing committee stage in February of the following year. After a two-year hiatus, the legislative process resumed in February 2015, but following the withdrawal of support by Sinn Féin - one of the two main political parties in the regional Executive - the

4 For an overview of key episodes, both violent and political, in the Northern Ireland 'troubles', see CAIN Web Service, 'Key Events of the Northern Ireland Conflict' <http://cain.ulst.ac.uk/events/> accessed 28 August 2013.

5 For an overview, see D G Byrne, The Irish Question and British Politics, 1866-1996 (Macmillan 1996); P Adelman and R Pearce, Great Britain and the Irish Question 1798-1921 (Hodder Education 2005); on the search for a settlement, see B Hadfield, 'The Belfast Agreement, Sovereignty and the State of the Union' (1998) Public Law 599; M McWilliams, 'Reflections of a Participant' in Mapping the Rollback? Human Rights Provisions of the Belfast/Good Friday Agreement 15 Years On, Report of a conference at Queen's University Belfast (26 April 2013).

6 P Hillyard, B Rolston and M Tomlinson, Poverty and Conflict in Ireland: An International Perspective (Institute of Public Administration/Combat Poverty Agency 2005); B Dickson, 'Counter-insurgency and Human Rights in Northern Ireland' (2009) 32(3) Journal of Strategic Studies 475; C Harvey and D Russell, 'A New Beginning for Human Rights Protection in Northern Ireland?’ (2009) 6 European Human Rights Law Review 748.

7 Human Rights Act 1998, c 42; Race Relations (Amendment) Act 2000, c 34; Disability Discrimination Act 2005, c 13; Equality Act 2006, c 3; Equality Act 2010, c 15.

8 The Agreement (n 1) c 6, para 2; Northern Ireland Act 1998, c 47, s 6(2).

9 The Agreement (n 1) c 6, para 4.

10 NIHRC, 'A Bill of Rights for Northern Ireland: Advice to the Secretary of State for Northern Ireland' (NIHRC 2008).

11 The Agreement (n 1) c 3, para 33(b).

12 Welfare Reform Bill (NIA Bill 13/11-15).

13 A partial legislative basis for this approach can be found in the Northern Ireland Act 1998, c 47, s 87; for discussion, see M Simpson, 'Social Security Parity in Northern Ireland: Developing Constitutional Principles through Firefighting?' (2015) 22(1) Journal of Social Security Law 31.

14 Welfare Reform Act 2012, c 5. 
Bill failed to pass final stage in May of that year. ${ }^{15}$ The main cause of the delay appears to have been the inability of the Executive parties to reconcile the view that the reforms included in the Bill represent an unjustifiable assault on the living standards of benefit claimants with fear that anything other than continued adherence to the Westminster model would represent an unsustainable financial burden for the region ${ }^{16}$ and the appeal to political unionism of the principle 'that an individual here in Northern Ireland should receive the same level of benefit, subject to the same conditions, as an individual elsewhere in the UK'. ${ }^{17}$

Discontent with the UK government agenda has been expressed by ministers in all three devolved regions. ${ }^{18}$ However, the Northern Ireland Assembly is in the unique position of having devolved competence for social security ${ }^{19}$ and is therefore currently the only regional legislature with the option of taking a different approach. ${ }^{20}$ This paper examines the potential impact of the Agreement's human rights provisions on the outcome of the debate as to the desirability of emulating reform in Great Britain. It argues that current obligations in respect of the ECHR rights should give regional legislators cause to reconsider one central aspect of the reform proposals, namely the sanctions that may be imposed on claimants who fail to meet conditions attached to receipt of benefit. However, equivalent judicial protection to socio-economic rights also protected by international law, but not incorporated into UK law, could have a further-reaching impact on the practice of maintaining parity. Given the opposition of unionist political parties and the UK government to the implementation in their current form of proposals for a Northern Ireland Bill of Rights, it is argued that the Agreement provision on compliance with international law in the region represents an alternative, and potentially more persuasive, vehicle for the protection of socio-economic rights.

The article begins with consideration of the nature of human rights and whether, as has previously been claimed, a qualitative difference exists between civil and political rights and social and economic rights that justifies or requires differential treatment in law. This proposition having been rejected, section 2 provides an overview of the human rights provisions of the Agreement, which are subsequently examined in turn. Following discussion of the limited (though real) potential for use of the ECHR in defence of socioeconomic rights and stalled progress towards a Northern Ireland Bill of Rights, the

15 See Northern Ireland Assembly, 'Welfare Reform Bill' (Northern Ireland Assembly 2015) <www.niassembly.gov.uk/assembly-business/legislation/primary-legislation-current-bills/welfare-reformbill $>$ accessed 24 March 2015. Sinn Fein's position is outlined in Sinn Fein, 'Welfare: The Facts' (Sinn Fein 2015) < www.sinnfein.ie/files/2015/Welfare-The-Facts.pdf> accessed 24 March 2015.

16 D Birrell and A M Gray, 'A View from Northern Ireland' in N Yeates, T Haux, R Jawad and M Kilkey (eds), In Defence of Welfare: The Impacts of the Spending Review (Social Policy Association 2011) 49; P Robinson, NIA Deb 9 October 2012, p 18; S Hamilton, NIA Deb 21 January 2014, vol 91, no 2, 3-4, 8-10; A Maskey, 'Hamilton Acting as Tory Cheerleader on Cuts - Alex Maskey' (Sinn Fein 16 March 2014) <www.sinnfein.ie/contents/29353> accessed 17 March 2014.

17 N McCausland in Committee for Social Development, Welfare Reform Bill: Ministerial Briefing (Official Report, Northern Ireland Assembly 31 January 2013) 2.

18 N Sturgeon, Scot Parl Deb 22 December 2011, session 4, cols 4941, 4943; Hamilton (n 16) 10; J Cuthbert and V Gething, 'Written Statement - Tackling Poverty Action Plan 2013' (Welsh Government 2013) <wales.gov.uk/about/cabinet/cabinetstatements/2013/tacklingpoverty/?lang=en> accessed 14 April 2014; N Sturgeon, 'Foreword from the Deputy First Minister' in Scottish Government, Child Poverty Strategy for Scotland: Our Approach 2014-2017 (Scottish Government 2014).

19 Social security features in the Scottish list of reserved powers and is absent from the Welsh list of delegated powers - see Scotland Act 1998, c 46, sch 5; Government of Wales Act 2006, c 32, sch 5.

20 The Scottish Parliament's likely future competences in the field of social security are set out in Scotland Office, Scotland in the United Kingdom: An Enduring Settlement (Cm 8990, Scotland Office 2015). 
prospects of the Agreement provision on the UK's international law obligations underpinning more rigorous protection of socio-economic rights are then considered. Finally, section 4 examines the likely practical implications for policymaking of a judicially enforceable obligation to comply with international law in the context of the current welfare reform controversy. It is concluded that, if the ECHR rights construct a persuasive argument against one aspect of envisaged reform, a general requirement to comply with the socio-economic rights instruments could raise wider questions about the appropriateness to Northern Ireland of the new approach in Great Britain. Although the principle of nonretrogression in socio-economic rights might prove difficult to argue before the courts, clearer statements on income security can be found across the various international instruments.

\section{Civil and political rights versus socio-economic rights: a false dichotomy?}

A theme central to this paper is the differential position in UK law of the ECHR, primarily associated with the protection of civil and political rights, and other international agreements more explicitly concerned with social and economic rights. At face value, this appears to mirror the oft-repeated contention that socio-economic rights differ qualitatively from civil and political rights and are consequently less suited to judicial enforcement. This section briefly examines the grounds for this contention, which are considered to be limited, before outlining the basis for justiciability or nonjusticiability of a right in the UK specifically.

Claims of the non-justiciability of socio-economic rights ${ }^{21}$ tend to emphasise that they are positive rights, requiring deliberate state intervention and thus a political decision to allocate resources, ${ }^{22}$ not negative rights requiring only non-interference with liberty, as civil and political rights are often portrayed. ${ }^{23}$ This argument sits uneasily alongside the fact that institutions for the exercise of political rights (representative bodies) and for upholding civil rights (courts) are not without cost. If no government has questioned whether the resources allocated should be maintained (a questionable assertion given criticism of the cost of local government and the courts), ${ }^{24}$ this is 'a matter of political culture and contingency', not the innate nature of such rights. ${ }^{25}$ So-called negative rights may themselves imply positive obligations such as a remedy for infringement, ${ }^{26}$ not mere non-

21 For discussion, see G McKeever and F Ni Aolain, 'Thinking Globally, Acting Locally: Enforcing Socio Economic Rights in Northern Ireland' (2004) 2 European Human Rights Law Review 158; C Gearty, 'Against Judicial Enforcement' in C Gearty and V Mantouvalou, Debating Social Rights (Hart 2011); J King, Judging Social Rights (CUP 2012).

22 For discussion of where the line between law and politics should be drawn, see King (n 21) 123.

23 R Plant, 'Citizenship, Rights and Welfare' in A Coote (ed), The Welfare of Citizens: Developing New Social Rights (Institute for Public Policy Research 1992) 18; S Fredman, Human Rights Transformed: Positive Rights and Positive Duties (OUP 2008) 3; see also A O'Hear, 'Hayek and Popper: The Road to Serfdom and the Open Society' in E Feser (ed), The Cambridge Companion to Hayek (CUP 2006) 134; D King and F Ross, 'Critics and Beyond' in F G Castles, S Leibfried, J Lewis, H Obinger and C Pierson (eds), The Oxford Handbook of the Welfare State (OUP 2010) 46.

24 A M Rees, 'The Promise of Social Citizenship' (1995) 23(4) Policy and Politics 313, 316; L Welsh, 'Neoliberalism and Access to Justice: Some Preliminary Findings' (Socio-Legal Studies Association Annual Conference, University of York March 2013); M Jacobs and T Wright, 'Tax and Spending (Again)' (2013) 84(2) Political Quarterly 177.

25 Rees (n 24) 316.

26 Articles 1 and 13 ECHR. 
interference, ${ }^{27}$ or only be realisable through removal of constraints on individuals' freedom to live as they see fit, such as lack of economic opportunity, education or health. ${ }^{28}$

The contention that the courts should not and cannot intervene in the social sphere has become increasingly indefensible. ${ }^{29}$ Civil, political, social, economic and cultural rights stand together in various documents ${ }^{30}$ and the European Court of Human Rights (ECtHR) recognises no 'water-tight division' between kinds of rights. ${ }^{31}$ Van Bueren argues that litigation on South Africa's constitutional duties in relation to housing 32 'hammered the final nail into the coffin of non-justiciability' to the extent that judges who accept their own lack of responsibility for upholding socio-economic rights are as much engaged in a 'political exercise' (here to determine the extent of their own remit) as those who adopt a more interventionist approach. ${ }^{33}$ However, the constitutional entrenchment of justiciable social rights in South Africa and a number of other states remains the exception rather than the rule. ${ }^{34}$

Claims of qualitative difference between types of rights are particularly difficult to sustain in the UK. With no one set of rights privileged with entrenched constitutional protection, ${ }^{35}$ rights in any sphere can potentially be created, enhanced, diminished or abolished by a government with a parliamentary majority. ${ }^{36}$ Here, the key distinction is between rights that form part of domestic law and those contained in international agreements that, although ratified by the state, have not been incorporated into domestic

27 For discussion, see B Dickson (guest ed), Special Issue: Positive Obligations and the European Court of Human Rights (2010) 61(3) Northern Ireland Legal Quarterly; in particular, B Dickson, 'Positive Obligations and the European Court of Human Rights’ (2010) 61(3) Northern Ireland Legal Quarterly 203, 203, argues that 'a duty to not do something can always (or virtually always) be re-phrased as a duty to do something' and that 'the idea that human rights can be adequately protected if states content themselves with merely standing by and doing nothing has become patently absurd'.

28 Fredman (n 23) 11.

29 For discussion, see I Byrne, 'A Legal Right to Wellbeing' (2005) 53 European Lawyer 54; E Palmer, Judicial Review, Socio-economic Rights and the Human Rights Act (Hart 2007).

30 Universal Declaration of Human Rights, adopted by General Assembly resolution 217A(III) of 10 December 1948; Charter of Fundamental Rights of the European Union (2007/C 303/01).

31 Airey v Ireland, App no 6289/73 [1979] 2 EHRR 305, para 26; Stec and Others $v$ UK [2006] ECHR 65731/01, 65900/01 para 52 (2006) 8(1) European Journal of Social Security 77; 93; see also E Myjer, 'The European Court of Human Rights and Social Justice' in I Lintel, A Buyse and B McGonigle Leyh (eds), Defending Human Rights: Tools for Social Justice (Intersentia 2012).

32 Government of the Republic of South Africa, the Premier of the Province of the Western Cape, Cape Metropolitan Council, Oostenberg Municipality v Irene Grootboom and Others, judgment of the Constitutional Court, 4 October 2000.

33 G van Bueren, 'Including the Excluded: The Case for an Economic, Social and Cultural Human Rights Act' (2002) Public Law 456; see also King (n 21) 3; for further discussion of the 'political' nature of judicial views of the remit of the courts, see C Gearty, 'On Fantasy Island: British Politics, English Judges and the European Convention on Human Rights’ (2015) 1 European Human Rights Law Review 1.

34 M Fordham, 'Social Rights' (2013) 18(4) Judicial Review 379, 380.

35 This is in contrast to the USA - see M T McCluskey, 'Efficiency and Social Citizenship: Challenging the Neoliberal Attack on the Welfare State' (2003) 78(2) Indiana Law Journal 783, 791.

36 See, for example, Criminal Justice and Public Order Act 1994, c 33, alleged to curb citizens' rights to freedom of movement, assembly and political expression; see also Rees ( $\mathrm{n} 24$ ); that Parliament's freedom to legislate thus may not be completely unrestrained is suggested in Jackson v Attorney General [2005] UKHL 56, para 102 (Lord Steyn), albeit that in many cases the constraints applicable to parliamentary power are self-imposed ibid, para 105 (Lady Hale). 
law through legislation. ${ }^{37}$ The ECHR does occupy a privileged position in UK law, but this is not because the rights conferred are civil and political rather than socio-economic numerous applicants have sought to use the ECHR in defence of socio-economic rights 38 - but because of its incorporation through the Human Rights Act 1998 and constitutional legislation for the devolved regions. ${ }^{39}$ The obligation on public authorities in Article 3(1) UN Convention on the Rights of the Child (UNCRC) to consider the best interests of the child when taking decisions affecting him or her also forms part of domestic law in 'spirit, if not the precise language' and, as shall be discussed in section 4, may have implications for socio-economic rights in cases involving children. ${ }^{40}$ Otherwise, a range of instruments concerned with socio-economic rights have been ratified by the UK but do not form part of domestic law. ${ }^{41}$ According to international law, such instruments are legally binding on state parties ${ }^{42}$ a position accepted to some extent by the UK in its statement that it does not 'ratify treaties unless confident that domestic law and practice is consistent with them'43 and in the requirement that ministers act in accordance with international obligations. ${ }^{44}$ However, in the dualist system there is no mechanism that requires compatibility of domestic legislation with international law: 'the sovereign power of the Queen in Parliament extends to breaking treaties'. ${ }^{45}$ Nor can any action be brought in the UK courts on the basis of infringement of a right conferred by a non-incorporated agreement, although

37 Cook and Another v Sir James Gordon Sprigg [1899] AC 572, 577 (Lord Halsbury); Rayner (Mincing Lane) Ltd v Department of Trade and Industry and Others; Maclaine Watson \& Co Ltd v Department of Trade and Industry; Maclaine Watson \& Co Ltd v International Tin Council [1990] 2 AC 418, 500 (Lord Oliver); J H Jackson, 'Status of Treaties in Domestic Legal Systems: A Policy Analysis' (1992) 86(2) American Journal of International Law 310; A W Bradley and K D Ewing, Constitutional and Administrative Law (Pearson Education 2003) 310-12.

38 For discussion, see A Gómez Heredero, Social Security as a Human Right: The Protection Afforded by the European Convention on Human Rights (Human Rights Files no 23, Council of Europe Publishing 2007); M Cousins, The European Convention on Human Rights and Social Security Law (Intersentia 2008); B Toebes, M Hartlev, A Hendriks and J Rothmar Herrmann, Health and Human Rights in Europe (Intersentia 2012); Myjer (n 31).

39 Human Rights Act 1998, c 42; Scotland Act 1998, c 46, s 29(2); Northern Ireland Act 1998, c 47, s 6(2); Government of Wales Act 2006, c 32, s 81.

$40 \mathrm{R}$ on the Application of SG and Others (Previously JS and Others) v Secretary of State for Work and Pensions [2015] UKSC 16, para 82 (Lord Reed); UNCRC, adopted by General Assembly resolution 44/25 of 20 November 1989, entry into force 2 September 1990, UN Treaty Series, vol 1577, 3; Children (Northern Ireland) Order 1995, no 755 (NI 2); Children Act 2004, c 31, s 11; Rights of Children and Young Persons (Wales) Measure 2010, nawm 2, s 1 .

41 Examples of relevance to the present discussion include ILO C102 - Social Security (Minimum Standards) Convention (Geneva, 28 June 1952, entry into force 27 April 1955); ESC (Turin, 18 October 1961, entry into force 26 February 1965, ETS035); ICESCR, adopted by General Assembly resolution 2200A (XXI), 16 December 1966, entry into force 3 January 1976, UN Treaty Series, vol 993, 3; the remaining UNCRC provisions.

42 Vienna Convention on the Law of Treaties, adopted 22 May 1969, entry into force 27 January 1980, UN Treaty Series, vol 1155, 331, Article 26.

43 United Kingdom of Great Britain and Northern Ireland, Implementation of the International Covenant on Economic, Social and Cultural Rights: Fifth Periodic Report submitted by States Parties under Articles 16 and 17 of the Covenant (E/C12/GBR/5, United Nations Economic and Social Council 2008) para 50.

44 HM Government, Ministerial Code (Cabinet Office 2010) para 1.2.

45 Salomon v Commissioners of Customs and Excise [1967] 2 QB 116, 143 (Diplock LJ); see also In the Matter of an Application by Caoimbin Mac Giolla Cathain for Judicial Review [2009] NIQB 66, in which it was held that the UK's ratification of the European Charter for Regional and Minority Languages could not in itself override the Justice (Language) Act (Ireland) 1737 requirement that court proceedings and documents be in English. 
interpretation of the ECHR rights and UK legislation can be shaped by those set out in such documents. ${ }^{46}$

This paper is not concerned with the principle of the sovereignty of the Queen in Parliament. ${ }^{47}$ The devolved legislatures are not sovereign and can only act within the competences delegated. ${ }^{48}$ If Parliament has been careful to reserve the right to legislate contrary to the ECHR, albeit against a strong presumption that it should not do so, no such flexibility is afforded to the devolved regions. These institutions therefore could be compelled to act in accordance with other international law. Although the Agreement suggests that this ought to be the case, at least in respect of Northern Ireland, current arrangements do not appear sufficiently robust to achieve the objective.

\section{Human rights in the Agreement}

Human rights feature prominently in the Agreement, most notably in the chapter on 'Rights, safeguards and equality of opportunity'. This commences with a declaration that the signatory parties 'affirm their commitment' to eight almost exclusively civil and political rights, the exception being the right to 'equal opportunity in all social and economic activity. ${ }^{49}$ More substantively, the chapter includes a commitment to establish a Northern Ireland Human Rights Commission (NIHRC) and, on the part of the UK government, to legislate for the incorporation of the ECHR into Northern Ireland law so as to render noncompliant legislation invalid. The remit of the NIHRC is to include the identification of rights 'supplementary' to those in the ECHR that require similar protection on the basis of the 'particular circumstances of Northern Ireland', which, collectively with the ECHR rights, are to form a regional Bill of Rights. ${ }^{50}$ The further requirement that Parliament 'legislate as necessary to ensure the United Kingdom's international obligations are met in respect of Northern Ireland' is also of relevance given that those obligations include the rights protected by a range of additional agreements ratified by the state. ${ }^{51}$ The extent of progress on each of these commitments varies.

Incorporation of the ECHR into the law of Northern Ireland has been delivered: the Northern Ireland Act 1998 stipulates that any Act of the Assembly, piece of subordinate legislation or act of a minister in the devolved Executive that is 'incompatible with any of the Convention Rights' (as defined by the Human Rights Act 1998) is outside the competence of the Assembly and therefore invalid. ${ }^{52}$ Similar provisions are found in the

46 Demir v Turkey [2009] App no 34503/97 48 EHRR 54, para 85; see also Sidabras v Lithuania [2006] App no 55480/00, 59330/00 42 EHRR 6, in which the court draws on Article 1(2) ESC when considering a complaint based on Articles 8 and 14 ECHR; for discussion of the use of the ECHR by the courts as an aid to statutory interpretation prior to its incorporation, see M Hunt, Using Human Rights Law in English Courts (Hart 1997) 131.

47 Other authors have questioned or identified exceptions to the general rule that Parliament can legislate exactly as it deems fit - see Bradley and Ewing (n 37) 60; D Sharp, 'Parliamentary Sovereignty: A Scottish Perspective' (2010) 6(1) Cambridge Student Law Review 135.

48 Scotland Act 1998, c 46, s 29; Northern Ireland Act 1998, c 47, s 6; Government of Wales Act 2006, c 32, ss $80-2,94$.

49 The Agreement (n 1) c 6, para 1.

50 Ibid c 6, paras 2, 4 .

51 Ibid c 3, para 33.

52 Northern Ireland Act 1998, c 47, s 6(2), s 24; Human Rights Act 1998, c 42, s 6. 
constitutional legislation for both Scotland and Wales. 53 The ECHR rights are afforded stronger protection in the devolved regions than in UK law generally. The Human Rights Act 1998, whose own future may be in doubt after the 2015 general election delivered a Conservative majority, ${ }^{54}$ allows the courts to declare an Act of Parliament or piece of subordinate legislation to be wholly or partially incompatible with the ECHR. However, the court may not invalidate primary legislation, or subordinate legislation where 'the primary legislation concerned prevents removal of the incompatibility'; nor does a declaration impose any legal requirement on ministers to remedy the incompatibility. ${ }^{55}$ In contrast, Acts of the devolved legislatures can be, and have been, declared invalid; in Salvesen, the court disapplied one provision of a Scottish Act with immediate effect and allowed a second to continue to have effect for a maximum of one year to allow the incompatibility to be remedied. ${ }^{56}$ In Northern Ireland, it appears that litigation could be commenced with the sole purpose of proving incompatibility; ${ }^{57}$ the High Court has held that the NIHRC could bring proceedings without itself being a victim of the incompatibility as long as the existence of a victim or potential victim could be demonstrated. ${ }^{58}$ Further, a Bill or proposed Measure that has completed its passage through a devolved legislature may be referred to the UK Supreme Court prior to royal assent if the Lord Advocate, Advocate General, Counsel General or Attorney General (depending on the region) considers it may fall outside the legislative competence of the region. ${ }^{59}$

While the devolved legislatures are each prevented from legislating contrary to the ECHR, the Agreement's proposal for a regional Bill of Rights is unique to Northern Ireland. Progress on this front has been more limited. The NIHRC completed its designated task with the presentation of its recommendations to the Secretary of State in 2008. ${ }^{60}$ However, this has not resulted in the publication by the UK government of proposals for a Bill of Rights, which, according to the Agreement, should be binding on the Northern Ireland Assembly in the legislative process in the same way as the ECHR. ${ }^{61}$ The principal reason for this lack of progress appears to be NIHRC's recommendation that a Bill of Rights should protect a range of socio-economic rights and dispute as to whether

53 Scotland Act 1998, c 46, ss 29(2), 54; Government of Wales Act 2006, c 32, ss 81, 94, 108; although Stewart has questioned whether Parliament really intended to put in place 'two competing human rights . . . jurisdictions' for the devolved regions, the effect of the legislation seems clear - see A Stewart, 'Devolution Issues and Human Rights' (2000) 30 Scots Law Times 239; I Jamieson, 'Relationship between the Scotland Act and the Human Rights Act' (2001) 5 Scots Law Times 43.

54 O Bowcott, 'Cameron's Pledge to Scrap Human Rights Act Angers Civil Rights Groups' The Guardian (London 1 October 2014) <www.theguardian.com/politics/2014/oct/01/cameron-pledge-scrap-humanrights-act-civil-rights-groups $>$ accessed 9 October 2014.

55 Human Rights Act 1998, c 42, s 4; N Bamford, 'Parliamentary Sovereignty and the Human Rights Act 1998' (1998) Public Law 572; Lord Irvine of Lairg, 'The Impact of the Human Rights Act: Parliament, the Courts and the Executive' (2003) Public Law 308.

56 Salvesen $v$ Riddell [2013] HRLR 23; the offending provisions were Agricultural Holdings (Scotland) Act 2003, asp 11, s 72(6) and (10).

57 Normally, and previously in Northern Ireland, a case under the Human Rights Act 1998 or ECHR may only be brought by a victim of a rights violation - see Human Rights Act 1998, c 42, s 7; Article 34 ECHR; Klass $v$ Germany [1978] 2 EHRR 214; Re Northern Ireland Commissioner for Children and Young People's Application for Judicial Review [2009] NI 235.

58 Re Northern Ireland Human Rights Commission's Application for Judicial Review [2012] Eq LR 1135, para 41 (per Treacy J); this judgment is on the basis of Northern Ireland Act 1998, c 47, s 71(2B).

59 Scotland Act 1998, c 46, s 33; Northern Ireland Act 1998, c 47, s 11; Government of Wales Act 2006, c 32, s 99.

60 NIHRC (n 10).

61 The Agreement (n 1) c 3, para 26(a). 
the protection of such rights represents an appropriate response to the 'particular circumstances of Northern Ireland'. 'Constitutional borrowing' and 'internationalisation' are frequently central to the drafting of Bills of Rights, ${ }^{62}$ as is arguably reflected in the Agreement's statement that a Bill might draw 'as appropriate on international instruments and experience'. ${ }^{63}$ Proponents of the entrenched protection of socio-economic rights further argue that many of the 'particular circumstances of Northern Ireland' are social, economic and cultural in nature, highlighting the link between socio-economic disadvantage and civil unrest and the potential for such rights to catalyse political engagement on a basis other than community affiliation. ${ }^{64}$ On the other hand, critics argue that the inclusion of socio-economic rights derived from international agreements - and therefore applicable to a wide range of societies - does not result in a proposal sufficiently tailored to the 'particular circumstances of Northern Ireland'. 65

Such debates aside, current political realities appear to offer limited prospect of a Bill of Rights including socio-economic rights being enacted in the foreseeable future. In Northern Ireland, unionist political parties have strongly opposed the NIHRC's recommendations in their current form. ${ }^{66}$ At UK level, the Prime Minister has also expressed scepticism about the NIHRC proposals ${ }^{67}$ and the Northern Ireland Office has argued that socio-economic rights 'are equally as relevant to the people of England, Scotland and Wales as they are to the people of Northern Ireland and, therefore, fall to be considered in a UK-wide context' rather than at regional level. ${ }^{68}$ Given the recommendations of the UK Commission on a Bill of Rights 69 and the 'antipathy' of politicians and media to 'the expansion of a "human rights agenda", 70 the prospects of socio-economic rights thus gaining enhanced protection seem equally scant. In Northern Ireland, desire to see the enactment of $a$ Bill of Rights any Bill of Rights - raises the possibility of a document being produced with a sole focus

62 A Smith, 'Internationalisation and Constitutional Borrowing in Drafting Bills of Rights' (2011) 60(4) International and Comparative Law Quarterly 867.

63 The Agreement (n 1) c 6, para 4.

64 B Dickson, 'New Human Rights Protections in Northern Ireland' (1999) 24 supp (human rights survey) European Law Review 3, 8; F McCausland, 'Why Northern Ireland (Still) Needs a Bill of Rights' (Groundhog Day: Five Years on from the Bill of Rights Advice, Belfast December 2013); P Kelly, 'Why Northern Ireland (Still) Needs a Bill of Rights' (Groundhog Day: Five Years on from the Bill of Rights Advice, Belfast December 2013); A Smith, M McWilliams and P Yarnell, 'Political Capacity Building: Advancing a Bill of Rights for Northern Ireland' (Transitional Justice Institute 2014); see also Hillyard et al (n 6).

65 Harvey and Russell (n 6); Northern Ireland Affairs Committee, 'A Bill of Rights for Northern Ireland: An Interim Statement' (HC236, incorporating HC360 i and ii, The Stationery Office 2010) ev 14-19; T Hadden, 'How the Bill Was Lost' (2010) (September) Fortnight, <www.nuzhound.com/articles/ Fortnight/arts2010/sep10_how_Bill_was_lost_THadden.php> accessed 10 January 2014; T Hadden, 'A Constitutional Bill of Rights for Communities and Individuals in Northern Ireland (Not a Bill of International Human Rights)' (Groundhog Day: Five Years on from the Bill of Rights Advice, Belfast December 2013).

66 J Donaldson, HC Deb 8 July 2009, vol 495, col 956; Democratic Unionist Party, 'Manifesto 2009: 1 Dodds' (Democratic Unionist Party 2009) 26; Ulster Unionist Party, 'Ulster Unionist Party Position on a Bill of Rights' (Ulster Unionist Party, year unknown).

67 'Tories Will Not Take McWilliams' Path - Cameron' News Letter (Belfast 27 May 2009) <www.newsletter.co.uk/news/regional/tories-will-not-take-mcwilliams-path-cameron-1-1885137> accessed 7 January 2014.

68 Northern Ireland Office, 'A Bill of Rights for Northern Ireland: Next Steps' (Consultation paper, NIO 2009) 17.

69 Commission on a Bill of Rights, 'A UK Bill of Rights? The Choice before Us: Volume 1' (Commission on a Bill of Rights 2012) 34.

70 B Dickson, Human Rights and the United Kingdom Supreme Court (OUP 2013) 36. 
on a limited range of civil, political and cultural rights around which consensus can be reached, with social and economic rights sidelined. ${ }^{71}$

The third Agreement provision of relevance to the protection of human rights, that Parliament should legislate to ensure fulfilment of the UK's international obligations in Northern Ireland, has thus far attracted less attention from academic authors and campaigners; the commitment has largely slipped from the agenda. This oversight appears surprising for a number of reasons. First, as a party to the Agreement, the UK government makes an explicit commitment to ensure its international obligations are met in respect of Northern Ireland, whereas its only firm commitment in respect of a Bill of Rights is to take account of the NIHRC's advice 'on the scope for defining, in Westminster legislation, rights supplementary to those in [the ECHR]'. ${ }^{72}$ Second, section 3 will suggest that the means by which Parliament has chosen to fulfil this commitment in the Northern Ireland Act 1998 may be portrayed as flawed. Third, insertion of a provision requiring that devolved legislation comply with, for example, the European Social Charter (ESC) or the International Covenant on Economic, Social and Cultural Rights (ICESCR) into s 6 and s 24 of the 1998 Act would immediately put the rights set out in those documents on equal footing with those in the ECHR without the convoluted process of negotiating and drafting a Bill of Rights ${ }^{73}$ that the NIHRC envisages would be strongly influenced by them. ${ }^{74}$ If amendment of the 1998 Act might seem a mundane means of protecting rights compared to achievement of the enactment of a Bill of Rights that has been assigned totemic status, ${ }^{75}$ it should be remembered that, in the UK, an Act of Parliament called a Bill of Rights is legally no different from any other Act of Parliament: it would be no more binding on the Northern Ireland Assembly and no better protected from repeal should Parliament change its mind.

That the ECHR has some relevance to the protection of socio-economic rights has been noted in section 1 and will be of interest in section 4 . Little more need be said about proposals for a Bill of Rights as the political climate is such that the delivery in the near future of a Bill including enhanced protection for social and economic rights appears fanciful. Further consideration of how the UK government might deliver on its commitment to ensure international obligations are met in Northern Ireland is required and forms the focus of section 3 .

\section{Ensuring compliance with international law in the devolution settlement}

The UK government's commitment to ensure that the state's obligations under international law are realised in Northern Ireland is clearly stated in the Agreement. One means of doing so is provided for in the constitutional legislation for all three devolved regions. However, it is argued here that this approach, based on political rather than judicial enforcement, is too dependent on voluntary action by the UK government of the day to offer effective protection of human rights. An alternative model, also used in all devolved regions but applicable only to the ECHR and EU law, not to other international law, has potential to underpin a more robust, judicial guarantee of the rights the state has committed to uphold on behalf of its citizens.

71 Discussion at 'Political Capacity Building: Advancing a Bill of Rights for Northern Ireland' (report launch, Stormont October 2014).

72 The Agreement (n 1) c 6, para 4.

73 For discussion of the process, see Harvey and Russell (n 6).

74 See NIHRC (n 10) 45-51.

75 For details of the ongoing campaign in favour of a Bill of Rights, see < www.billofrightsni.org>. 
The devolution legislation empowers the Secretary of State to ensure devolved ministers comply with the UK's international obligations by directing them to take, or not to take, certain actions as necessary. ${ }^{76}$ Such actions may include the making of secondary legislation and the introduction of a Bill to the devolved legislature. ${ }^{77}$ Primary legislation may not be revoked by order, but the Secretary of State could presumably direct that a minister in a devolved administration introduce a Bill to amend or repeal a previous Act or Measure. It is therefore possible for the devolved institutions to be bound by unincorporated international law in a way that Parliament is not. However, this is dependent on the exercise of political discretion by the UK government, not on enforcement by an independent judiciary: the Secretary of State is not obliged to direct that a particular action be taken or not taken even if it appears that international obligations are likely to be breached.

In contrast, under the ECHR model, which is outlined in section 2 above, it is not for the Secretary of State but for the courts to decide whether devolved legislation or acts of devolved ministers comply with the ECHR and, if appropriate, to declare legislation invalid or (as in Salvesen) ${ }^{78}$ to order amendment. This means that a decision as to whether to challenge the validity of legislation lies with a victim whose rights have allegedly been infringed or (in Northern Ireland) with the NIHRC, or (prior to royal assent) the Advocate General, Lord Advocate, Counsel General or Attorney General; ${ }^{79}$ the ultimate decision on compliance rests with the courts, not with a politician who may or may not wish to investigate or act upon possible non-compliance in a given case. Invalidity because of lack of devolved competence is not limited to non-compliance with the ECHR. An Act of the Northern Ireland Assembly would also be invalid if contrary to EU law, purporting to apply outside Northern Ireland, dealing with an excepted matter, discriminatory on the basis of religious belief or political opinion ${ }^{80}$ or, perhaps, violating 'constitutional common law principles'. ${ }^{81}$ Some similar grounds for invalidity exist in Scotland and Wales. ${ }^{82}$

A hierarchy of means of ensuring compliance with international law therefore emerges. Although international treaties in principle place a legal obligation on state parties to fulfil the obligations entered into, ${ }^{83}$ to which the UK at least pays lip-service, ${ }^{84}$ in practice there is often no means of enforcing these obligations. Accountability mechanisms are often political rather than legal, such as the reports on compliance produced by the European Committee of Social Rights (ECSR) and Committee on Economic, Social and Cultural Rights (CESCR); even where a judicial body exists, the UK may not agree to its jurisdiction, as with the procedures instituted by the optional protocol to the ICESCR and the additional

76 Scotland Act 1998, c 46, s 58; Northern Ireland Act 1998, c 47, s 26; Government of Wales Act 2006, c 32, s 82.

77 For discussion of whether Acts of the Scottish Parliament represent primary or subordinate legislation, see A McHarg, 'What is Delegated Legislation?' (2006) Public Law 539.

78 Salvesen $v$ Riddell [2013] HRLR 23.

79 Such a challenge has occurred, although not on human rights grounds - see Local Government Byelaws (Wales) Bill 2012 - Reference by the Attorney General for England and Wales [2013] 1 AC 792.

80 Northern Ireland Act 1998, c 47, s 6(2); the 1998 Act stipulates some grounds for invalidity other than those listed above.

81 Re CM's Application for Judicial Review [2013] NIQB 145, para 4, 13 (Treacy J).

82 Scotland Act 1998, c 46, s 29; Government of Wales Act 2006, c 32, ss 80, 94, 108; Axa General Insurance v Lord Advocate [2012] 1 AC 686, para 51 (Lord Hope), para 143 (Lord Reid).

83 Vienna Convention on the Law of Treaties (n 42).

84 United Kingdom of Great Britain and Northern Ireland ( $\mathrm{n} 43$ ) para 50; HM Government ( $\mathrm{n}$ 44) para 1.2. 
protocol to the ESC, neither of which has been signed by the state. ${ }^{85}$ No legislature or state institution could be compelled to abide by the terms of such instruments in the absence of specific domestic law to that effect. The current model in the devolution legislation provides one means of compelling a devolved legislature to do so. This approach has the advantage of not requiring a complaint from an individual who claims his or her rights have been infringed, but is weakened by reliance on political rather than judicial enforcement. If, as shall be discussed in section 4, the UK government may be accused of non-compliance with its international obligations in a given field, it could hardly be expected to hold a regional administration to account for the same failings. The ECHR model, as it applies at devolved level, is much more robust, providing for the invalidation of non-compliant legislation by the courts on the basis of non-compliance alone, independent of political calculation. The need for an individual who has suffered an alleged rights violation to initiate proceedings might in some cases prevent non-compliant legislation being exposed to judicial scrutiny due to the absence of a willing applicant, but in Northern Ireland at least the ability of the NIHRC to litigate in its own name in the absence of a named victim addresses this risk. A similar model for other human rights instruments would not only greatly strengthen their judicial weight, but would require their closer consideration in the political process.

A revised s 6 of the Northern Ireland Act 1998, amended with this objective in mind, might then read:

\section{Legislative competence}

(1) A provision of an Act is not law if it is outside the competence of the Assembly.

(2) A provision is outside that competence if any of the following paragraphs apply$\cdots$

(c) It is incompatible with any of the rights set out in the relevant Agreements.

(2A) In s 6(2)(c), the relevant Agreements are:

(a) The European Convention on Human Rights

(b) Those articles of the European Social Charter accepted by the United Kingdom

(c) The United Nations Convention on the Rights of the Child

Subsection 2A could be then amended over time to incorporate such international instruments as the UK government deemed ought to be binding on the devolved institutions.

85 Additional Protocol to the European Social Charter providing for a system of collective complaints (Strasbourg, 9 November 1995, entry into force 1 July 1998, CETS158); Optional Protocol to the ICESCR adopted by General Assembly resolution 63/117 (LXIII), 5 March 2009, GAOR 63rs, sess, supp 49; see also Council of Europe Treaty Office, 'Additional Protocol to the European Social Charter Providing for a System of Collective Complaints CETS no 158: status as of 27/8/2014' (Council of Europe 2014) $<$ http:/ / conventions.coe.int/Treaty/Commun/ChercheSig.asp?NT $=158 \& C M=\& D F=\& C L=E N G>$ accessed 27 August 2014; Office of the High Commissioner for Human Rights, 'Ratification Status for ICESCR-OP - Optional Protocol to the International Covenant on Economic, Social and Cultural Rights' (UN 2014). <http://tbinternet.ohchr.org/_layouts/TreatyBodyExternal/Treaty.aspx?'Treaty=CESCR \&Lang=en $>$ accessed 27 August 2014. 
The key question for this section is whether the UK government has lived up to its commitment in the Agreement to ensure fulfilment of its international obligations in respect of Northern Ireland. Certainly, through s 26 of the Northern Ireland Act 1998, Parliament confers upon the Secretary of State the power necessary to ensure that the Assembly and Executive do not act contrary to the state's international obligations. This in turn must create a significant incentive for those institutions to ensure their actions are compliant with international law. Indeed, there is evidence of this obligation being taken seriously at regional level, in the form of Assembly committee investigations in Northern Ireland ${ }^{86}$ and legislation in Wales. ${ }^{87}$ However, should a regional legislature act contrary to human rights obligations, the Secretary of State is under no obligation to intervene. When, as in section 4, the source of the alleged rights infringement is UK legislation whose provisions are essentially being duplicated in the devolved region, such an intervention must be particularly unlikely. In such circumstances, the only truly effective protection of human rights may be through the judiciary.

\section{Enter the Welfare Reform Bill: the potential impact of judicially protected socio-economic rights}

The Welfare Reform Act $2012^{88}$ may be fairly described as the flagship legislative achievement of the Conservative-Liberal Democrat Coalition government of 2010 to 2015. The main stated objectives of the Act may be described as (1) simplification of the social security system, (2) encouragement of transition from benefits to employment and (3) 'fairness' to those in employment. ${ }^{89}$ The means employed in pursuit of these objectives have generated considerable hostility from civil society campaign groups ${ }^{90}$ and from devolved governments. If the most vocal opposition has arguably come from Scotland's governing Scottish National Party, ${ }^{91}$ of the devolved regions only Northern Ireland is currently in a position to translate its concerns about UK government policy into a distinctive regional approach. ${ }^{2}$ However, given the long-established convention that the region's social security system mirror that in Great Britain, underpinned by its weak fiscal position and the statutory requirement to consult the UK government on the desirability of maintaining common provision, ${ }^{93}$ a compelling case would have to be made for any significant policy divergence. The extent to which such a case can be made may depend in large measure on the implementation of the human rights provisions of the Agreement.

86 Ad-hoc Committee, Report on Whether the Provisions of the Welfare Reform Bill are in Conformity with the Requirements for Equality and Observance of Human Rights (NIA 92/11-15, Northern Ireland Assembly 2013).

87 Rights of Children and Young Persons (Wales) Measure 2011, nawm 2, which is designed to enhance the status of UNCRC in that region.

88 Welfare Reform Act 2012, c 5.

89 See I Duncan Smith, HC deb 9 March 2011, vol 524, col 919; Department for Work and Pensions (DWP), 'Simplifying the Welfare System and Making Sure Work Pays' (DWP 2014) <www.gov.uk/government/policies/simplifying-the-welfare-system-and-making-sure-work-pays> accessed 27 August 2014.

90 See, for example, P Walker, 'UK Uncut Joins Fight against Welfare Reform Bill' The Guardian (London 25 January 2012) <www.theguardian.com/uk/2012/jan/25/uk-uncut-welfare-tax-disability> accessed 27 August 2014.

91 See Sturgeon (n 18) col 4943; Scottish National Party, Press Release 'UK's Catastrophic Welfare Changes Set to Bite' (1 April 2013) <www.snp.org/media-centre/news/2013/apr/uks-catastrophic-welfare-changes-setbite> accessed 17 February 2014; N Sturgeon (n 18).

92 The revision of Scotland's devolution settlement following the 2014 referendum on independence will include devolved competence for some aspects of social security - see Scotland Office (n 20).

93 Northern Ireland Act 1998, c 47, s 87. 
Northern Ireland has since 1920 been the only UK region with devolved competence for social security. ${ }^{94}$ However, since 1926 the UK Exchequer has financially underwritten the maintenance of a parallel but in almost all respects similar system for the region compared to that in Great Britain, an approach that would at most points in Northern Ireland's history otherwise have represented a heavy, if not unaffordable, fiscal burden. ${ }^{95}$ The UK government currently subsidises contributory benefits in Northern Ireland ${ }^{96}$ and funds non-contributory benefits in their entirety, at a cost of $f 334 \mathrm{~m}$ and $f 2.9 \mathrm{bn}$ respectively in 2012-2013. ${ }^{97}$ This arrangement, which could once readily be portrayed as the 'most important item' of policy for the 'removal of want' in Northern Ireland, ${ }^{98}$ has been increasingly questioned since the 1980s. ${ }^{99}$ The long delay in the progress - and ultimate failure - of the current Welfare Reform Bill ${ }^{100}$ is the result of a clash between the two main parties in the consociational Executive. ${ }^{101}$ The Democratic Unionist Party has stressed the fiscal risks associated with abandonment of parity and (to a lesser extent) the convention that all UK citizens should enjoy the same social entitlements on the same terms, ${ }^{102}$ while Sinn Fein expresses opposition to 'Tory cuts' to public services without providing clear information on how it would fund an alternative approach. ${ }^{103}$

Public discourses on the desirability or otherwise of implementing reforms to mirror those in Great Britain have tended to be political and economic, rather than legal, in nature. However, the scrutiny process undergone by the Bill does indicate that the Assembly has been alive to the possibility of provisions contravening human rights obligations, an ad hoc committee having been appointed to consider this issue. ${ }^{104}$ The committee concluded by majority vote that no specific breaches could be identified. However, concerns about compliance with specific human rights provisions - particularly Article 8 ECHR and

94 The powers of the Parliament of Northern Ireland are set out in the Government of Ireland Act 1920, c 67, ss 4 and 9, and generally mirror those envisaged for an Irish 'home rule' Parliament in the Government of Ireland Act 1914, c 91, ss 2 and 14.

95 Relevant legislation includes Unemployment Insurance (Northern Ireland Agreement) Act 1926, c 4; Social Services (Northern Ireland Agreement Act) 1949, c 23; Social Security Administration (Northern Ireland) Act 1992, c 8, s 153; for further details, see J Bradshaw, Social Security Parity in Northern Ireland (Policy Research Institute 1989); L Lundy, 'Parity, Parrotry or Plagiarism? Legislating for the Unemployed Poor in Northern Ireland 1838-1995' in N Dawson, D Greer and P Ingram (eds), One Hundred and Fifty Years of Irish Law (SLS Legal Publications 1996); Simpson (n 13).

96 Funds are transferred from the National Insurance Fund for Great Britain to that for Northern Ireland so as to maintain the balance in the Northern Ireland fund at $2.84 \%$ of the combined total; in 2012-2013, this arrangement resulted in a transfer of $£ 334 \mathrm{~m}$, but payments from the fund still exceeded receipts by $£^{255 \mathrm{~m}-}$ see HM Revenue and Customs, Northern Ireland National Insurance Fund Account for the Year Ended 31 March 2013 (HC 894, The Stationery Office 2013) 2, 11.

97 Department for Social Development (DSD), Resource Accounts for the Year Ended 31 March 2013 (DSD 2013).

98 B Brooke, HC (NI) Deb 2 March 1949, vol 33, col 37.

99 N Raynsford in HSS Committee, Report on Proposal for a Draft Housing Benefits (NI) Order (NIA 51, 11 May 1983 ) appendix 2 calls for the abandonment of parity in favour of using Northern Ireland as a testing ground for new approaches to social security; HSS Committee, Report: Social Security Parity (NIA 141-I, 26 June 1984) 5.3 advocates a special supplementary unemployment benefit and fuel benefit for Northern Ireland; E Evason, 'Poverty in Northern Ireland' (1986) 75(300) Irish Quarterly Review 503 argues that higher energy costs mean levels of cash benefits that are adequate for Great Britain are not for Northern Ireland.

100 See Northern Ireland Assembly, 'Welfare Reform Bill' (Northern Ireland Assembly 2015) <www.niassembly.gov.uk/assembly-business/legislation/primary-legislation-current-bills/welfare-reformbill> accessed 25 March 2015; Sinn Fein (n 15); Simpson (n 13).

101 Birrell and Gray (n 16) 49.

102 Robinson (n 16); Hamilton (n 16) 10.

103 A Maskey, 'Sinn Féin Calls for Deferral of the Welfare Reform Bill' (Sinn Féin 4 October 2012) <www.sinnfein.ie/contents/24642> accessed 17 March 2014; Maskey (n 16).

104 Ad-hoc Committee (n 86). 
Article 3(1) UNCRC - were raised in written submissions and Sinn Fein members argued that the Bill as drafted was likely to result in human rights infringements. ${ }^{105}$ Simpson argues that there is a strong possibility of the sanctions regime for claimants who breach conditions associated with receipt of a benefit - that they be available for paid employment, actively seeking paid employment and/or undertaking activities intended to improve their prospects of securing employment - breaching ECHR obligations. ${ }^{106}$ In particular, it is argued that by denying access to the financial resources necessary for the satisfaction of essential needs, ${ }^{107}$ sanctions applied to households including dependent children may violate the child's right to family life under Article 8 ECHR. ${ }^{108}$ There is also a risk of noncompliance with Protocol 1 Article 1 ECHR due to concerns about proportionality, effectiveness and arbitrariness of sanctions that mean the public interest test for interference with an proprietary right may not be passed. ${ }^{109}$

Given that the Northern Ireland Assembly lacks competence to legislate contrary to the ECHR, it would be well advised to take these issues into account; indeed, a ministerial amendment tabled at consideration stage would have limited the maximum duration of a sanction in Northern Ireland to 18 months, compared to 36 in Great Britain, ${ }^{110}$ although the extent of support available through hardship payments would have been a matter for secondary legislation. Changes to the sanctions regime, though, would not address every potential human rights concern relating to the reformed social security system. Other particularly controversial features of the reformed social security system include provision for compulsory, unpaid work placements, ${ }^{111}$ reduction of the maximum available housing benefit including an under-occupancy penalty for social tenants (commonly referred to as

105 See, for example, the NIHRC submission at 324, Northern Ireland Welfare Reform Group submission at 344 and the Save the Children submission at 351.

106 M Simpson, “Designed to Reduce People ... to Complete Destitution”: Human Dignity in the Active Welfare State' (2015) 1 European Human Rights Law Review 66; failure to comply with these conditions can result in loss of Jobseeker's Allowance (JSA) or the standard allowance element of universal credit for a maximum of 156 weeks - see Jobseekers Act 1995, c 18, part i; Jobseeker's Allowance (Mandatory Work Activity) Regulations 2011, no 688; Welfare Reform Act 2012, c 5, pt 1, c 2, pt 2, cc 1-2; Universal Credit Regulations 2013, no 376, reg 110; Jobseeker's Allowance Regulations 2013, no 378, pt 3.

107 The judgment in $\mathrm{R}$ on the Application of Refugee Action v Secretary of State for the Home Department [2014] ACD 99 calls into question the ability of hardship payments to enable claimants subject to sanctions to meet essential needs and demonstrates clearly that an individual without access to a hardship payment would have insufficient income to do so.

108 For the principle that Article 8 may create a positive obligation to provide financial support when the welfare of children is at stake, see Ala Anufrijeva v London Borough of Southwark; $\mathrm{R}$ on the Application of $N v$ Secretary of State for the Home Department; $\mathrm{R}$ on the Application of Mv Secretary of State for the Home Department [2004] 2 WLR 603, para 43 (Lord Woolf); $R$ on the Application of Jamil Sanneh v Secretary of State for Work and Pensions, Commissioners for HMRC v Birmingham City Council [2013]ACD 99, paras 44-6 (Hickinbottom J).

109 Hentrich v France, App no 13616/88) [1994] 18 EHRR 440, para 2; R on the Application of SRM Global Master Fund LP v Commissioners of HM Treasury [2009] UKHRR 1219, para 81 (Stanley Burton LJ and Silber J); P T Orebech, 'From Diplomatic to Human Rights protection: The Possessions under the 1950 European Human Rights Convention, First Additional Protocol Article 1' (2009) 43(1) Journal of World Trade 59; D Webster, 'Independent Review of Jobseeker's Allowance (JSA) Sanctions for Claimants Failing to Take Part in Back to Work Schemes: Evidence Submitted by Dr David Webster' (Child Poverty Action Group 2014) <www.cpag.org.uk/sites/default/files/uploads/CPAG-David-Webster-submission-Oakley-review-Jan14_0.pdf> accessed 19 May 2014.

110 Northern Ireland Assembly, 'Welfare Reform Bill Marshalled List of Amendments (Annotated)' (Northern Ireland Assembly 2015) < www.niassembly.gov.uk/assembly-business/legislation/primary-legislation-currentbills/welfare-reform-bill/marshalled-list-of-amendments-consideration-stage-tuesday-10-february-2015> accessed 23 February 2015.

111 Jobseeker's Allowance (Schemes for Assisting Persons to Obtain Employment) Regulations 2013, no 276. 
the 'bedroom tax') ${ }^{112}$ and the capping of households' maximum overall benefit income. ${ }^{113}$ There is no need to discuss in detail the issue of compulsory work placements, the Supreme Court having held in Reilly that such schemes do not constitute forced labour contrary to Article $6 \mathrm{ECHR},{ }^{114}$ and therefore do not violate the right to free choice of occupation in other human rights instruments. ${ }^{115}$ The provisions potentially resulting in reduced benefit income do raise issues regarding compliance with human rights instruments other than the ECHR, which might mean lack of competence to legislate contrary to them would have a profound influence on Northern Ireland's response to the reforms in Great Britain.

Social security benefits in the UK largely play the role occupied by social assistance 116 in continental welfare states of relieving or alleviating poverty and ensuring a minimum standard of living for some of the most disadvantaged members of society. Any measure that results in lower incomes for claimants must therefore raise questions of compliance with the presumption of non-retrogression in social rights. ${ }^{117}$ This requires that there should be no diminution of citizens' social rights 'except under specific circumstances'.118 However, specific retrogressive measures may be acceptable if the state can demonstrate that it considered all alternatives and that retrogression in this field enables better use of available resources in pursuit of the realisation of the suite of social rights as a whole. ${ }^{119}$ While it may be claimed that reform of out-of-work and disability benefits represents an unjustified retrogressive step given the reduction of income that will result for some claimants, ${ }^{120}$ it is equally arguable that there is 'no magic figure [of public expenditure] that's going to guarantee or undermine human rights' and that decisions as to priorities must always be made. ${ }^{121}$ If, as the UK government claims, overall reduction of public spending proves beneficial to the economy, realisation of the full suite of socio-economic rights

112 Housing Benefit Regulations 2006, no 213, reg B13, inserted by Housing Benefit (Amendment) Regulations 2012, no 3040, reg 5; Rent Officers (Universal Credit Functions) Order 2013, no 382, s 3, sch 1.

113 Housing Benefit Regulations 2006, no 213, pt 8A, inserted by Benefit Cap (Housing Benefit) Regulations 2012, no 2994, reg 2; Universal Credit Regulations 2013, no 376, pt 7.

$114 \mathrm{R}$ (on the Application of Reilly and Another) $v$ Secretary of State for Work and Pensions [2014] AC 453, paras 80 and 83 (Lord Neuberger and Lord Toulson); see also Xv Netherlands [1976] 7 DR 161.

115 ESC Article 1(2), ICESCR Article 6; see also European Roma Rights Centre v Bulgaria, complaint 48/2008 [2009] 49 EHRR SE12; Schuitemaker v Netherlands, App no 15906/08 [2010] (unreported) 4 May 2010; CESCR, General Comment No 18: The Right to Work (E/C12/GC/18, UN 2006) 4; European Committee of Social Rights, European Social Charter: Addendum to Conclusions XV-1 (Council of Europe 2001).

116 A normally non-contributory cash benefit of last resort - see S Jones, 'Achieving an Adequate Minimum Income in Europe' (Social Consequences of the Crisis, Brussels, 22 February 2013).

117 Article 2(1) ICESCR; Article 4 UNCRC.

118 M Sepúlveda, The Nature of the Obligations under the International Covenant on Economic, Social and Cultural Rights (Intersentia, 2003) 319; see also CESCR, General Comment No 14: The Right to the Highest Attainable Standard of Health (E/C12/2000/4, UN 2000) 9.

119 CESCR, General Comment no 19: The Right to Social Security (Article 9) (E/C12/GC/19, UN 2008) 13.

120 A Donald, 'Austerity Opposition Needs a Coherent Narrative. Human Rights Provides One' The Guardian (London 25 January 2011) <www.theguardian.com/commentisfree/libertycentral/2011/jan/25/humanrights-fairness-austerity-cuts> accessed 20 January 2014; A Nolan, 'Is the Government's Austerity Programme Breaking Human Rights Law?' (Open Democracy 1 March 2011) $<$ www.opendemocracy.net/ourkingdom/aoife-nolan/is-governments-austerity-programme-breakinghuman-rights-law> accessed 20 January 2014; P O'Connell, 'Let Them Eat Cake: Socio-economic Rights in an Age of Austerity' in A Nolan, R O'Connell and C Harvey (eds), Human Rights and Public Finance: Budgets and the Promotion of Economic and Social rights (Hart 2013).

121 Lord McNally and K Clarke in 'Joint Committee on Human Rights, The Government's Human Rights Policy (HC 609i 2010-2011) (uncorrected transcript of oral evidence) <www.publications.parliament.uk/ $\mathrm{pa} /$ jt201011/jtselect/jtrights/uc609-i/uc60901.htm> accessed 20 January 2014. 
might be advanced if this were to lead to increased employment at adequate wages. ${ }^{122}$ The Court of Appeal has already recognised the maintenance or strengthening of work incentives by reducing benefit payments to be a 'fundamental legitimate objective' capable of justifying some negative impact on some claimants. ${ }^{123}$ Therefore, even if the relevant international agreements could be relied on in court, the vagueness of the nonretrogression principle means its judicial enforcement would be difficult.

General provisions in the international agreements on what constitutes an acceptable or adequate living standard also suffer from lack of precise definition and may therefore be difficult to translate into a minimum acceptable income, ${ }^{124}$ other than with reference to existing UK case law, ${ }^{125}$ and may in some cases apply specifically to workers rather than all citizens. ${ }^{126}$ It might be arguable that the right of the child to 'a standard of living adequate for ... physical, mental, spiritual, moral and social development' ${ }^{127}$ ought to be interpreted in accordance with the income and material deprivation standards established by the Child Poverty Act 2010, ${ }^{128}$ but this would have to be tested by the courts.

Specific provisions on social security and social assistance are clearer as to the income levels required for compliance. The pre-2012 level of social security benefits in the UK was already 'manifestly inadequate' to comply with the Article 12 ESC provision on social security, ${ }^{129}$ being below 40 per cent of equivalised median income for most claimant groups. This might form the basis for a legal challenge to the level of contributory benefits if the ESC were justiciable in the UK. Likewise, unemployment benefits have never matched the level required by Article 66 International Labour Organization Convention 102 (ILO C102), 45 per cent of an unskilled worker's wage. ${ }^{130}$ However, the state pension aside, most so-called social security benefits in the UK are more akin to the ESC definition of

122 G Osborne, 'New Year Economy Speech by the Chancellor of the Exchequer' (HM Treasury 2014) <www.gov.uk/government/speeches/new-year-economy-speech-by-the-chancellor-of-the-exchequer> accessed 20 January 2014.

$123 \mathrm{R}$ on the Application of SG and Others (previously JS and others) v Secretary of State for Work and Pensions v Child Poverty Action Group, Shelter Children's Legal Service [2014] HRLR 10, paras 46-50, 56 (Lord Dyson); this judgment was upheld by the Supreme Court in R on the Application of SG and Others (previously JS and Others) v Secretary of State for Work and Pensions (n 40) see also Hoogendijk $v$ Netherlands [2005] 40 EHRR SE22.

124 Article 11 ICESCR requires income sufficient to acquire basic necessities, plus (possibly) 'a further amount... reflecting the cost of participating in the everyday life of society' - see World Bank, World Development Report 1990: World Development Indicators (OUP 1990)

125 For example, $\mathrm{R}$ on the Application of Refugee Action v Secretary of State for the Home Department [2014] ACD 99.

126 Article 7(a) ICESCR; Article 4(1) ESC.

127 Article 27 UNCRC.

128 C 9, ss 2-6 - the Act sets targets for the near-eradication of child poverty, defined as living in a household with income below $60 \%$ of equivalised median in current year, below $60 \%$ of equivalised median in 2010-2011 adjusted for inflation, below 70\% of equivalised median and unable to afford specified items deemed necessities or below $60 \%$ of equivalised median in three of the last four years.

129 Note that the UK accepts only Article 12(1) and not the subsequent paragraphs - see European Committee of Social Rights, European Social Charter: Conclusions XX-2 (2013) (Great Britain) (Council of Europe 2014).

130 Committee of Experts on the Application of Conventions and Recommendations, Direct Request, adopted 2007, published 97th ILC session (2008): Social Security (Minimum Standards) Convention, 1952 (No 102) UK. 
social assistance. ${ }^{131}$ Their appropriateness is therefore better judged against Article 13. In the past, the UK has been found to comply with this article, which requires that combined income from all benefits received should not be 'manifestly below' 50 per cent of equivalised median income. ${ }^{132}$ This finding can be questioned - other research suggests childless households on means tested benefits could typically expect an income of no more than 30 per cent of equivalised median ${ }^{133}$ - and the capping of benefit income ${ }^{134}$ has potential to increase the number of claimant households with children whose income falls significantly below the 50 per cent threshold. ${ }^{135}$ Local housing allowance reform is likely to have a similar effect if, as housing advisors have reported, landlords are disinclined to reduce rents in response to resulting reductions in housing benefit, forcing claimants to redirect a portion of non-housing benefit income to make up the shortfall. ${ }^{136}$ The courts have recognised that the benefit cap discriminates against lone parents, and by extension against women, but nonetheless held that it did not contravene the ECHR rights as these negative effects could be justified by the 'fundamental legitimate objective' the policy was introduced to achieve. ${ }^{137}$ Future ECSR reports will provide further insight into whether judicially enforceable ESC rights in Northern Ireland might have the potential to result in a different judgment.

Further potential consequences for social security claimants of the reforms discussed in the previous paragraph include loss of housing due to inability to pay rent or inability to acquire housing in some areas as landlords become reluctant to let to claimants. ${ }^{138}$ In the main, it appears that the socio-economic rights instruments offer such individuals no additional protection compared to the ECHR, both Article 8 ECHR and the housingrelated provisions of ICESCR having been mainly interpreted as primarily protecting from arbitrary eviction rather than conferring an absolute right to a home. ${ }^{139}$ The best prospect for an action on the basis of homelessness so caused would appear to be Article 8 ECHR

131 In 2012-2013, payments of contributory JSA and Employment and Support Allowance (ESA) in Great Britain totalled $f 4.2 \mathrm{bn}$, compared to $f 16.7 \mathrm{bn}$ spent on means-tested JSA, ESA and Income Support and a further $f^{57.2 b n}$ on means-tested housing benefit, council tax benefit and tax credits - see Department for Work and Pensions (DWP), Budget 2013 Expenditure Tables (HM Government, 2013); DWP, Department for Work and Pensions Annual Report and Accounts 2012-2013 (HC 20, DWP 2013); DWP, Outturn and Forecast Budget 2014: Summary Tables (DWP 2014); for definitions of social security and social assistance, see Committee of Independent Experts, Conclusions XIII-4 (Council of Europe 1996) 34.

132 European Committee of Social Rights (n 129) 22.

133 The Poverty Site, 'Poverty Indicators: State Benefit Levels' <www.poverty.org.uk/12/index.shtml> accessed 16 August 2013.

134 Welfare Reform Act 2012, c 5, ss 96-7; Benefit Cap (Housing Benefit) Regulations 2012, no 2994.

$13550 \%$ of households in Great Britain affected by the benefit cap, and 63\% of those in Northern Ireland, are projected to be lone-parent families - see DWP, 'Benefit Cap (Housing Benefit) Regulations 2012: Impact Assessment for the Benefit Cap' (DWP 2012); DSD, 'Northern Ireland Benefit Cap Information Booklet' (DSD 2013).

136 B Reeve-Lewis, ‘Tenants Driven from Private Rented Sector in Anticipation of Benefit Cap' The Guardian (London 10 June 2013) < www.theguardian.com/housing-network/2013/jun/10/tenants-private-rentedsector-benefit-cap> accessed 28 March 2014.

$137 \mathrm{R}$ on the Application of SG and Others (n 123) paras 46-50, 56 (Lord Dyson).

138 Reeve-Lewis (n 136); A Gentleman, 'The Families priced out of their London Homes by Benefit Cap' The Guardian (London 5 March 2014) <www.theguardian.com/society/2014/mar/05/families-priced-outlondon-homes-benefit-cap> accessed 28 March 2014.

139 Chapman v UK [2001] 33 EHRR 18, para 99; St Brice and Another v London Borough of Southwark [2002] 1 WLR 1537, para 21 (Kennedy LJ); R on the Application of HC v Secretary of State for Work and Pensions, Secretary of State for Local Government and Communities, HM Revenue and Customs v Oldham Metropolitan Borough Council [2013] EWHC 3874 (Admin), para 71 (Supperstone J); CESCR, 'General Comment No 7: The Right to Adequate Housing (Article 1 Paragraph 1 of the Covenant)' in Economic and Social Council, Official Records, 1998: Supplement No 2 (E/1998/22, UN 1998). 
for households including children or Article 3 ECHR for rare adult applicants whose circumstances are such as to constitute inhuman or degrading treatment.

The compliance of one aspect of recent social security reform in Great Britain, the stiffened sanctions regime, with the UK's ECHR obligations may be questioned. A judicial challenge on the basis of Article 8 or Protocol 1 Article 1 would provide welcome clarification. Further potential issues emerge when the proposed reforms are compared to the state's obligations under other international human rights instruments. The nonretrogression principle may be seen to be sufficiently flexible to allow some retrogression in some areas, possibly including reduction of the level of cash benefits, and is thus likely to provide a poor basis for a legal challenge to an individual policy decision. Nonetheless, benefits must be above a certain minimum level to comply with provisions on social security and social assistance, including Article 66 ILO C102 and Articles 12 and 13 ESC. As has been demonstrated, the UK's compliance with at least two of these three articles can be questioned.

The practical consequences at devolved level of non-compliance varies depending on the region and the instrument concerned. Wales and, until now, Scotland lack competence for social security and therefore the opportunity to develop an alternative approach. In Northern Ireland, a finding of incompatibility of the sanctions regime with the ECHR rights would render the Assembly incapable of following its usual policy of emulating social security policy in Great Britain as it lacks competence to legislate contrary to ECHR. The position in relation to the other instruments is less clear-cut. Both the Agreement and the Northern Ireland Act 1998 suggest that devolved legislation ought to comply with the UK's international obligations generally. However, with enforcement currently in the hands of the Secretary of State, it would be extremely surprising if the UK government were on human rights grounds to prevent Northern Ireland following a course central government had itself set. As with ECHR at present, judicial oversight would form a more effective means of protecting human rights. If the devolved institutions were similarly debarred from acting contrary to international law generally, adherence to the Great Britain model, already under political pressure, could become legally problematic even outside the narrow field of sanctions.

\section{Discussion and conclusion}

The UK government has given a 'solemn commitment to support, and where appropriate implement' the provisions of the Good Friday Agreement. ${ }^{140}$ The extent to which it has done so in respect of the document's human rights provisions is mixed. Incorporation of the ECHR into the law of Northern Ireland has been achieved, and in a manner that binds the devolved legislature to a much greater extent than its incorporation into UK law binds Parliament. The commitment to consider recommendations from the NIHRC on the desirable content of a Bill of Rights for Northern Ireland might be argued to have been delivered upon, although it currently seems unlikely that any Bill of Rights will be enacted by Parliament as a result, and almost certain that any such Bill would not enhance the protection of socio-economic rights beyond that afforded by the ECHR. Finally, the requirement to legislate to ensure the state's international obligations are fulfilled in Northern Ireland finds expression in political oversight of the actions of devolved institutions, but has no judicial element and confers no binding obligation on the Secretary of State to take action.

140 Agreement between the Government of the United Kingdom of Great Britain and Northern Ireland and the Government of Ireland (Belfast, 10 April 1998, TS50 (2000) Cm 4705) (British-Irish Agreement) Article 2. 
As a result, protection of social and economic rights in Northern Ireland is weaker than would have been the case had these been included in a Bill of Rights or had other human rights instruments been afforded equal status to the ECHR in the constitutional legislation. An approach reflecting the ECHR model would have important implications for current and future social security reforms considered by the devolved legislature. It is already possible to question whether the Northern Ireland Assembly has competence to introduce a sanctions regime equivalent to that now in force in Great Britain, due to possible incompatibility with the protection of human dignity underpinned by Articles 3, 8 and Protocol 1 Article 1 ECHR. If the ESC, the ILO C102 or the UNCRC were equally binding on the Assembly, such doubts might extend to the level of benefits. The long-established practice of parity in social security between Great Britain and Northern Ireland, already under strain to the political controversy that surrounds the UK government reform agenda, might also become legally difficult to sustain.

Such a development would raise serious economic and fiscal issues which fall beyond the scope of this paper. Given the extent of central subsidy to Northern Ireland's formally separate social security system, the affordability of more generous provision there would inevitably be questioned, in keeping with the familiar debate over the definition of 'maximum available resources' in socio-economic rights instruments. ${ }^{141}$ Previous literature has argued that contributory benefits and those benefits that form the core of the UK's 'social union' are ill suited to regional control or payment at different rates in different regions. ${ }^{142}$ Whether the risk of fiscal difficulties - which could be exacerbated if claimants from other regions migrated to Northern Ireland in order to take advantage of a higher level of support ${ }^{143}$ - could outweigh the requirements of the international agreements and whether the UK government should underwrite higher benefit levels if these were necessitated by obligations imposed by Parliament would be hotly contested politically. Any perception from Scotland or Wales that provision for citizens' welfare in Northern Ireland had improved in comparison to Great Britain could also be expected to have implications for demand for full devolved competence in those regions. ${ }^{144}$

The present paper does not pretend to offer a solution to these complex considerations that would accompany a strict requirement to comply with socio-economic rights

141 For discussion, see R E Robertson, 'Measuring State Compliance with the Obligation to Devote the "Maximum Available Resources" to Realising Economic, Social and Cultural Rights' (1994) 16 Human Rights Quarterly 693; van Bueren (n 33); R Balakrishnan, D Elson, J Heintz and N Lusiani, Maximum Available Resources and Human Rights: Analytical Report (Center for Women's Global Leadership 2011); D Elson, R Balakrishnan and J Heintz, 'Public Finance, Maximum Available Resources and Human Rights' in Nolan et al (n 120).

142 K C Wheare, Federal Government (Greenwood Press 1963) 156; P Sutherland, 'Social Security Law and Administration from an Australian Perspective' (Ulster Law Clinic seminar, Belfast 13 June 2013); G Lodge and A Trench, Devo More and Welfare: Devolving Benefits and Policy for a Stronger Union (Institute for Public Policy Research 2014).

143 For a previous warning of this risk, see J Craig, HC (NI) Deb 22 September 1931, vol 13, col 1945; residence tests for some benefits were previously more onerous in Northern Ireland than in Great Britain because of the perceived risk of migration from the Irish Free State and later Republic of Ireland - see T Fahey and E McLaughlin, 'Family and State' in A F Heath, R Breen and C T Whelan (eds), Ireland North and South: Perspectives from Social Science (Proceedings of the British Academy 1998/OUP 1999) 128; N Yeates, E McLaughlin and G Kelly, 'Social Security in Ireland, North and South' in N Yeates and G Kelly, Poverty and Social Security: Comparing Ireland, North and South (report on seminar hosted by Statistics and Research Branch, DSD and Social Security Research Group, Dundalk, November 2001) 2.2.

144 Northern Ireland's Finance Minister claimed in 2014 that his counterparts in Scotland and Wales were 'incredibly jealous' of the region's devolved competence for social security, even as he cautioned against any expectation that more than minor departures from the approach in Great Britain would be feasible - see Hamilton (n 16) 4. 
agreements applied to a devolved region but not to the national legislature. It does highlight an apparent gap between the commitments entered into in 1998 by the UK government in respect of human rights in Northern Ireland and subsequent legislation (or, in the case of the Bill of Rights, lack of). Delivery in full on these commitments would call into question the policy of every government of Northern Ireland since 1920, whether devolved or direct rule, that social security in the region should almost without exception mirror that in Great Britain, a policy whose future under the current Executive already appears less certain than at almost any point in the history of Northern Ireland. 
